\title{
Why and What Did Legal Scholars Write in Medieval Islamic Societies?
}

\author{
Maribel Fierro \\ Institute of Languages and Cultures of the Mediterranean, CSIC-Madrid
}

\begin{abstract}
Maribel Fierro's motivating question is "[w] hy books dealing with specific subjects were written at specific times and in specific contexts." Relying on a dataset compiled by Historia de los Autores y Transmisores de al-Andalus (HATA), a project she directs that aims to map the intellectual production of al-Andalus, the author observes that the majority of scholarship produced by Andalusi scholars were fiqh and poetry texts. The former, she argues, is likely explained by the professional opportunities enabled by engaging in the study of figh at the time compared to other genres. What makes such research possible is the breadth of the dataset, in no small way thanks to the collegial sense of some of the scholars during the Andalusi era, exemplified by the case of Ibn al-Tallā' (d. 497/1104) whose Kitāb aqdiyat rasūl Allāh lists thirty-four of the sources he relied on.
\end{abstract}


$\mathrm{T}$ he Cordoban Mālikī scholar Ibn al-Ṭallā' (d. 497/1104) authored a number of legal books dealing with contracts (wathä $i q$ ), patronate (wala '), and other subjects. He also decided to write a book on the judgments or sentences issued by the Prophet Muhammad, the Kitāb aqdiyat rasūl Allāh, when he realized that the subject had been largely overlooked: he found only one book, by Abū Bakr b. Abī Shayba (d. 235/849), which he described as being "small."'13 That 'small book' (kitāb șaghīr) is in fact included in Ibn Abī Shayba's Mușannaf; to my knowledge, sections devoted to aqdiyat rasūl Allāh or ahkām al-nabī are not found in other hadit $\underline{t} h$ compilations, although the hadiths quoted by Ibn Abī Shayba can be found in them under other headings. Hajjī Khalīfa (d. 1067/1657), in his Kashf al-zunūn, mentions Ibn al-Ṭallā's work, of which he must have seen a copy, since he quotes its opening passage. He also mentions another work on the topic, the Kitāb aqdiyat rasūl Allāh written by the Hanafi scholar Zāhir al-dīn 'Alī b. 'Abd al- 'Azīz b. 'Abd al-Razzāq al-Marghinānī (d. 506/1112). ${ }^{14}$ Later, in his supplement to Hajjī Khalīfa's bibliographical compilation, the Hadiyyat al-'ärifin, Ismā' īl Bāshā al-Baghdādī mentions another early author, the Egyptian Mālikī scholar Muḥammad b. Aṣbagh b. al-Faraj (d. 275/888), who wrote a book on Aqdiyat al-rasül that Ibn alȚallā' does not seem to have had knowledge of, and which now seems to be lost. ${ }^{15}$ While Hajjī Khalīfa asserts that al-Marghinānī's work gave rise to commentaries, ${ }^{16}$ such was not the case with Ibn al-Ṭallā's work. It did, however, circulate widely, with at least eight manuscripts preserved, mostly in Turkish libraries but also in India, and with more than six modern editions from

13 'Abd Allāh Muhammad ibn Faraj al-Mālikī al-Qurțubī Ibn alṬallā', Aqdiyat Rasūl Allāh (Miṣr: 'Īsá al-Bābī al-Halabī, 1927), 125-26.

14 Hājjīi Khalīfa, Kashf al-ẓunūn, ed. G. Flügel, 4 vols (Leipzig, 183558,) I, 379-80.

15 Ismā'īl Bāshā al-Baghdādī, Hadiyyat al- 'ārifìn, asmā' al-mu'allifin wa-äthār al-mușannifin, 2 vols. (Istanbul 1951), who also records two later works on the same subject, one by Abū 1-Ṭayyib Muhammad Șadīq Khān al-Hindī (d. 1307/1889) and another by the Shî'î scholar Asad Allāh Ibn al-Ḥājj Ismā'îl al-Kāzimī (d. 1220/1805).

16 This work is not included in Carl Brockelmann, Geschichte der Arabischen Litteratur, 2 vols. +3 vols.: Supplementenbänden, 2nd ed. (Leiden: E. J. Brill, 1943-49). I do not know if it has been preserved. 
1927 to 2003 , as well as a translation into Urdu. ${ }^{17}$

Ibn al-Tallā' was careful to explain the state of the art (although he omits Ibn al-Așbagh's work) and lists the thirty-four works that he used as sources. ${ }^{18}$ By doing so, we may recognize in him a 'colleague,' a scholar who did things the way they ought to be done. Making the effort to fill a gap in the extant literature on a subject seems to us a commendable undertaking in the scholarly world today, and one that by itself could explain why Ibn al-Ṭallā' wrote his book. Should we look further into the matter? One may think that interest in the sentences of the Prophet would have been widespread among the Shāfi 'is and the Hanbalīs. Why then did a Mālikī like Ibn al-Ṭallā' think that the subject deserved more attention than that offered by Abu Bakr b. Abī Shayba? Did it have to do with the fact that those sentences were issued while the Prophet was living in Medina and therefore would have influenced the judicial practice there, a matter of importance for the Mālikīs given the relevance they accorded to Medinese 'amal? But then why was it that a Hanafi who was a contemporary of Ibn al-Tallā' also became interested in the same subject at around the same time in another region of the Islamic world? Is this another one of those synchronicities that are not uncommon in the global Islamic world of knowledge, and that point to specific needs or trends in the scholarly milieu or even in society at large?

Why books dealing with specific subjects were written at specific times and in specific contexts is an issue that has interested me since the time I started doing research back in the 1980s. Spanish Arabism had as one of its missions to translate into Spanish the works written in al-Andalus in order to make them available to other scholars - mostly Medievalists - who did not have competence in Arabic, as these works were believed to offer relevant materials for writing the 'history of Spain.' My

17 This information is taken from Historia de los Autores y Transmisores de al-Andalus (HATA), directed by M. Fierro, http://kohepocu.cchs.csic. es/ and https://www.eea.csic.es/red/hata/

18 On which see Maribel Fierro, "La Fahrasa de Ibn al-Ṭallā'," in Estudios Onomástico-Biográficos de al-Andalus. II, ed. María Luisa Avila (Granada: CSIC, 1989), 277-97. 
initial interest was in those Muslims and Islamic beliefs and practices that were subject to accusations of innovation, deviation and heresy in al-Andalus. I translated two books by Andalusi authors_-Ibn Waḍḍāḥ al-Qurțubī (d. 287/900) and al-Ṭurțūshī (d. 520/1126) - dealing with innovations mostly in rituals (bida', sing. bid'a), and in both cases it took me a long time to reach a satisfactory understanding - at least in my view. ${ }^{19} \mathrm{I}$ was greatly helped in eventually reaching this understanding by the fact of directing a project that had the aim of mapping the intellectual production of al-Andalus, Historia de LOS AUtORES Y Transmisores DE AL-ANDALUS. ${ }^{20}$ In HATA, the materials are organized in chronological order by author and discipline, one of which is Islamic law $($ fiqh $) .^{21}$

Fiqh was undoubtedly the discipline most cultivated by Andalusi scholars, as reflected in TABLE 1, which covers the period between 93/711 and 325/936. Just a note regarding the case of poetry: what the Table reflects by 'Poetry' are not works such as poetic dīwann-s, but verses - in some cases just a few of them-mentioned in the sources from which the materials of HATA have been extracted. Poetry in fact had a pervasive presence in Andalusi society, as it formed part of the daily life of the cultivated elites.

19 M. Fierro, "Al-Ṭurțusshī and the Fatimids," in Farhad Daftary and Shainool Jiwa, eds., The Fatimid caliphate: Diversity of traditions (London-New York: IB Tauris and the Institute of Ismaili Studies, 2017), 118-62.

20 See note 5.

21 The 'disciplinary' division required us to make decisions that were often difficult and not always completely satisfactory in much the same way that everyone who has used the reference work that inspired the structure of HATA - Fuat Sezgin, Geschichte des Arabischen Schrifttums, 15 volumes (Leiden: Brill, 19672010) - has probably discovered. 


\section{WORKS WRITTEN BY ANDALUSIS}

WORKS WRITTEN BY NON-ANDALUSIS

years $93 / 711-325 / 936$

Data taken from the History of the Authors and Transmitters of al-Andalus (HATA)

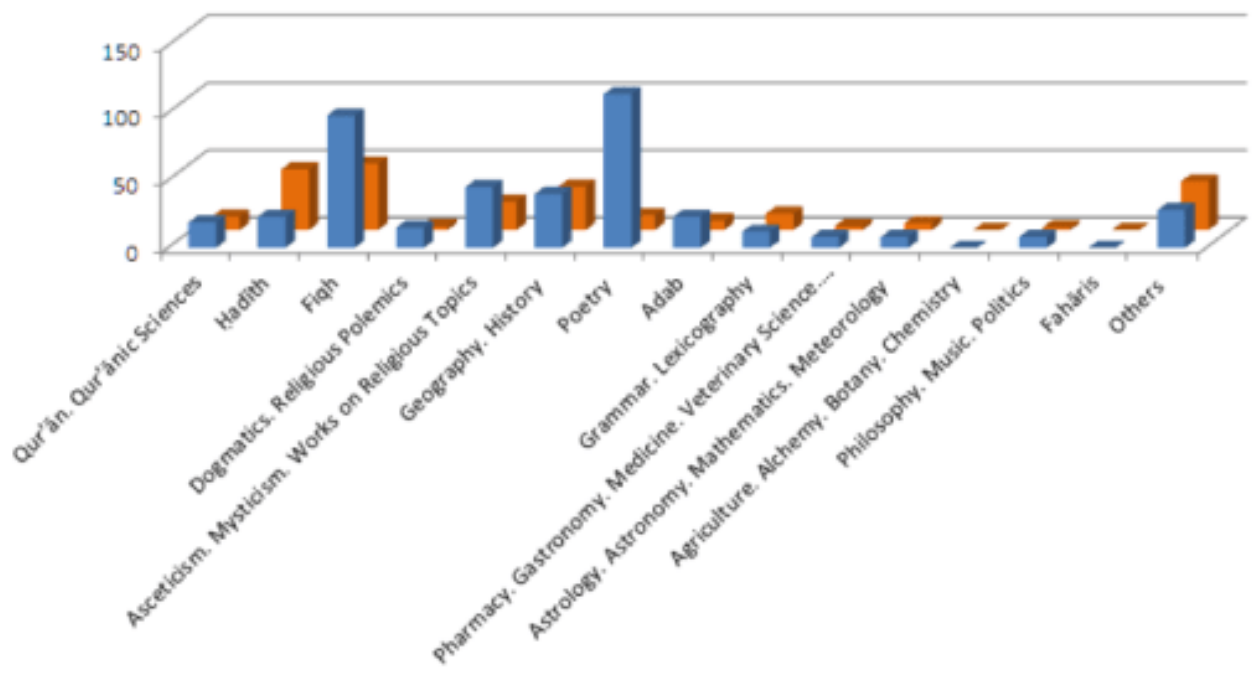

The prevalence of fiqh over other disciplines, as revealed in TABLE 1, is in principle unsurprising: after all, fiqh offered more professional opportunities than other fields of study. What is more noteworthy is how rapidly early Andalusi legal scholars began to shape, through works of their own, the reception of what they had learned during their travels to the East. The dynamics of the pedagogical process were undoubtedly relevant

22 Tables 1 and 2 are taken from Maribel Fierro, "Knowledge transfer and production in early al-Andalus: Travel, scholars and book circulation," to appear in a book edited by Nikolas Jaspert (Heidelberg). I wish to thank him for giving permission to reproduce the Tables here. 
in this respect. The data found in HATA also reveal trends that could otherwise have been missed, for example how the effort to compile fatāwa and the type of resulting compilation-devoted to just one author or paying attention to specific regions and thus including legal opinions from many scholars - can be related to specific political situations in the Islamic West. ${ }^{23}$

Of special interest is how figh was related to other disciplines and how such relations changed through time. Dominique Urvoy was a pioneer in highlighting the different ways in which knowledge was structured according to different historical periods through the exploitation of the data found in the biographical dictionaries of scholars. ${ }^{24}$ It is now possible to broaden and complement Urvoy's findings thanks to new resources including not only HATA, but also the Prosopography of the 'Ulama $\vec{a}$ ' of al-Andalus ${ }^{25}$ and the Biblioteca de al-Andalus. ${ }^{26}$

The number of available primary texts has also hugely increased since I started my academic career. Back then, when working on Ibn Waḍḍāh's Kitāb al-bida', very few works written in the 3rd/9th century that would have helped me in contextualizing his work were accessible even if preserved, and most were considered to have been lost. Now the situation has radically changed in general with respect to source materials from the Islamic world at that time, and in particular for al-Andalus, as shown in TABLE 2. HATA lists 147 legal works that circulated in al-Andalus between 93/711-325/936; of them, 49 were written

23 Maribel Fierro, "Compiling fatāwa in the Islamic West (third/ninthninth/fifteenth centuries)," Jerusalem Studies in Arabic and Islam 49, forthcoming. In this article I develop a finding that I first pointed out in "La religión," in El retroceso territorial de al-Andalus. Almorávides y almohades. Siglos XI al XIII), vol. VIII/2 Historia de España R. Menéndez Pidal, ed. M. J. Viguera (Madrid: Espasa Calpe, 1997), 435-546, chapter 2, note 25.

24 Dominique Urvoy, Le monde des ulémas andalous du V/XIe au VII/ XIIIe siècle (Genève: Librairie Droz, 1978).

25 Prosopografía de los ulemas de al-Andalus (PUA), directed by María Luisa Ávila, online access at https://www.eea.csic.es/pua/

26 Jorge Lirola Delgado and José Miguel Puerta Vílchez, eds., Biblioteca de al-Andalus, 7 vols. (Almería: Fundación Ibn Tufayl de Estudios Árabes, 20042012); Jorge Lirola Delgado, ed., Apéndice (Almería: Fundación Ibn Tufayl de Estudios Árabes, 2013); La producción intelectual andalusí: balance de resultados e indices (Almería: Fundación Ibn Tufayl de Estudios Árabes, 2013). 
by non-Andalusi authors and 98 by Andalusi authors. Of these 98, 60 have been preserved, a figure I find quite striking given that these data refer to such an early period.

TABLE 2

\section{PRESERVED WORKS BY ANDALUSIS}

years 93/711-325/936

Data taken from the History of the Authors and Transmitters of al-Andalus (HATA)

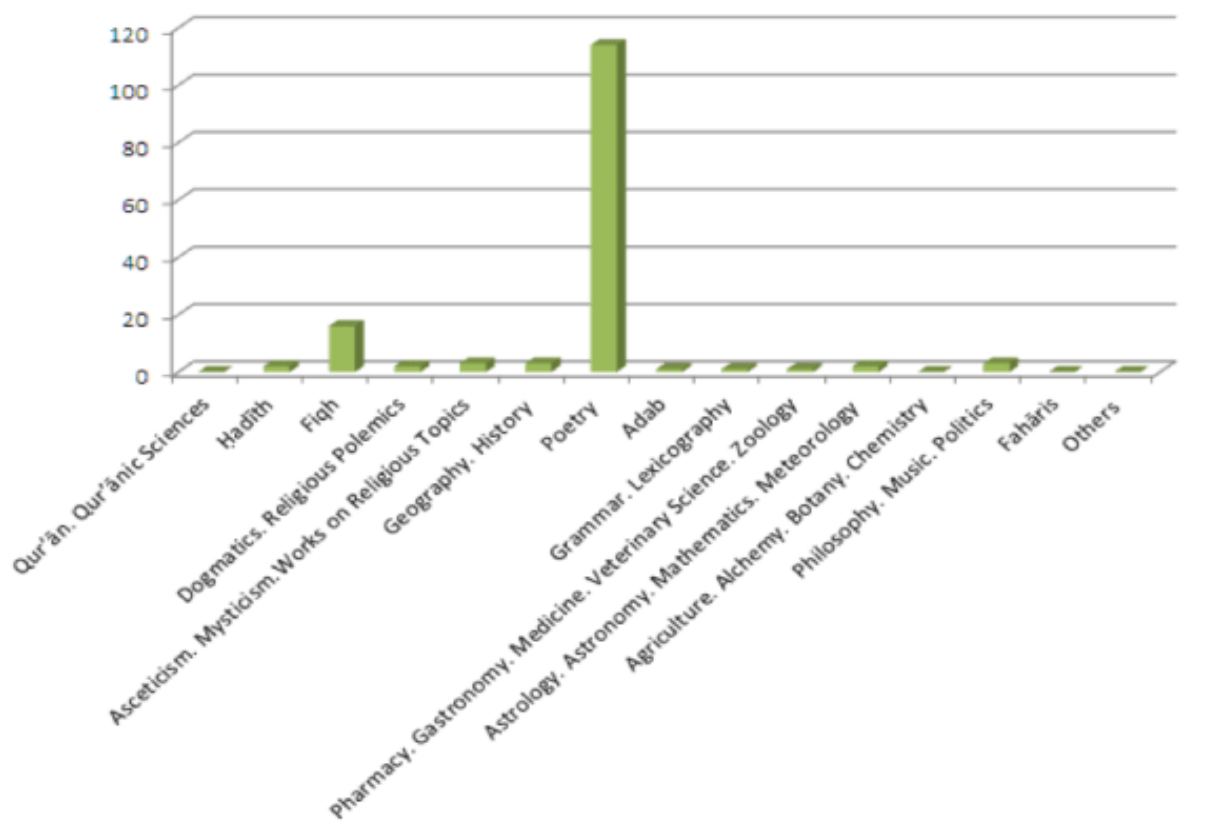

To sum up, for the case of legal writings in al-Andalus, we are now in the best possible circumstances for analyzing a variety of issues, such as:

- the rate of survival of works written between the $2 \mathrm{nd} / 8$ th9th/15th centuries and how, where and why they have been preserved;

- historical developments regarding the appearance of specific genres and how they relate to specific political situations;

- which works were the object of commentaries and how the writing of such commentaries influenced the transmission of the 
original works $;{ }^{27}$

- the popularity of certain works, how long their popularity lasted, and why;

- the identification of certain 'canons' in legal literature, especially in association with teaching, and how they evolved through time.

In order to make full sense of the data for al-Andalus collected in HATA - data obtained from biographical dictionaries, fahäris, historical works, quotations in other works, catalogues of manuscripts and many other sources - they should be compared with those of other regions, and in order to do so, similar data will need to be made available, something that will hopefully become a reality in the future. These kinds of resources will be of great help to fully grasp what motivated, for example, Ibn al-Ṭallā' and al-Marghinānī to tackle the Prophet's rulings simultaneously in disparate contexts.

27 The Mustakhraja min al-asmi a mimmā laysa fì l-Mudawwana by al'Utbī (d. 255/869) seems to have stopped circulating as an independent work after Ibn Rushd al-Jadd (d. 520/1126) wrote his commentary Kitāb al-bayān wa'l-taḥșil wa'l-sharh wa'l-tawjīh wa-ta 'līl li-masā'il al-'Utbiyya as noted by Ana Fernández Félix, Cuestiones legales del islam temprano. La 'Utbiyya y el proceso de formación de la sociedad islámica andalusí (Madrid: CSIC, 2003). 